\title{
Biomaterials Development for Application in Tissue Engineering: Literature Review
}

\author{
Taís dos Santos Costa ${ }^{1^{*}}$ \\ ${ }^{\text {I} S E N A I ~ C I M A T E C ~ U n i v e r s i t y ~ C e n t e r, ~ H e a l t h ~ I n s t i t u t e ~ o f ~ T e c h n o l o g y ; ~ S a l v a d o r, ~ B a h i a, ~ B r a z i l ~}$
}

\begin{abstract}
The search for tissue regeneration has attracted a lot of attention due to its wide applicability, and great potential to solve several problems in advanced therapies. Currently, functional systems have been widely used as therapeutic solutions in the treatment of some skin diseases, whether chronic, acquired, or as a consequence of accidents and burns. It is possible due to the feasibility of releasing and/or acting in loco of some active substances with properties and characteristics very similar to human skin. In this sense, this work aimed to carry out a literature review research regarding the development of new biomaterials, including hydrated membranes composed of biopolymers such as keratin and bacterial cellulose. Keywords: Hydrated Membranes. Biopolymers. Properties.
\end{abstract}

\section{Introduction}

In recent decades, the biopolymer market has been a growing interdisciplinary area due to its countless alternatives of wound recovery and disease treatments. In the field of tissue engineering, biomaterials are used to recover tissue from an injured area.

Injuries caused by burns are the field of application of hydrated membranes. Their function is to promote cell proliferation for tissue reconstitution, keeping the wound moist, therefore, less painful. The moisture also facilitates the dressing exchange process, or even makes it dismissable, since a fully degradable membrane is one of the explored possibilities by tissue engineering.

Therefore, the objective of this work is to carry out a literature review on the development of hydrated membranes composed of chitosan and bacterial cellulose biopolymers. They are widely explored in this area for their great potential to achieve the key features for a biomaterial.

\footnotetext{
Received on 18 March 2021; revised 16 May 2021.

Address for correspondence: Taís dos Santos Costa: Centro Universitário SENAI CIMATEC; Av. Orlando Gomes, $1845-$ Piatã, Salvador - BA - Brazil. Zipcode: 41.650-010. E-mail: taisdscosta@gmail.com.

J Bioeng. Tech. Appl. Health

(C) 2021 by SENAI CIMATEC. All rights reserved.
}

\section{Material and Methods}

The present study is a literature review realized between December 2020 to February 2021, by consulting articles previously indicated and archives of periodicals such as Scielo, PubMed, and ScienceDirect.

At first, a search for biomaterials was carried out, followed by the most common forms of hydrated membrane production for dressing wounds, as well as their desired characteristics and the materials used. Finally, it was made a final search about articles related to the synthesis of these membranes and the analysis of their properties. All the analyzed research dates from the 2000s until now.

\section{Essential Characteristics and Properties of a Biomaterial}

For a useful biomaterial, it must present indispensable basic characteristics and properties.

\section{Biocompatibility}

Biocompatibility is a property related to the ability of adhesion and interaction between the biomaterial and the cells [1]. A biocompatible material enables the exchange of cellular materials to occur normally and prevents the body from rejecting the inserted material [1]. 
Non-Toxic Biodegradability

Since one of the main goals is to allow the growth of new cells, the biomaterial must be able to degrade [2]. This property refers to the ability of a biomaterial to degrade in the body, releasing components that won't cause cell death in the surrounding cells $[1,2]$. Therefore, it is extremely important to know the byproducts generated from the degradation of a material.

\section{Compatible Mechanical Properties}

Mechanical properties of a biomaterial must be compatible with the area where it will be inserted, allowing the component to be able to support the mechanical solicitations without breaking or overloading other organs or tissues, and allowing the patient to move normally [1].

These properties are affected by the geometry of the hydrated membrane scaffold, the material, and the strength-enhancing materials of which it is constituted [3].

\section{Essential Characteristics and Properties of a Hydrated Membrane}

The most important role of a hydrated membrane is to promote cell proliferation of injured tissue, so it can reconstitute itself. However, one of the main difficulties in the treatment of injuries caused by burns is to change the dressings causing minimum pain for the patient. Keeping the lesion moist is important both to facilitate this exchange, to avoid infection, and to reduce fluid loss. Achieving those requirements are the standard protocol for burn management healing [4]. Therefore, it is necessary to keep these needs in mind so that the properties related to them are properly covered.

\section{$\underline{\text { Biomimetics }}$}

Biomimetic is a property related to the ability to stimulate cell proliferation [5]. As previously mentioned, since the main goal of a hydrated membrane is to allow the damaged tissue to grow again, the biomaterial must be biomimetic.

\section{Wettability}

Since moisture is extremely important for a hydrated membrane, the biomaterial must be hydrophilic, so the interaction between the membrane and the tissue increases. This property is evaluated through the measurement of wettability, which is determined by the tangent angle between a drop of a liquid and the surface where it relies on [6]. If this angle is less than $90^{\circ}$, then the analyzed material is hydrophilic, if it is greater than $90^{\circ}$, the material is considered non-hydrophilic [6].

\section{Geometry and Porosity}

The geometry of a scaffold affects many attributes besides the mechanical properties. To function properly, tissue must be able to exchange biological nutrients and waste. Therefore, to reconstitute a damaged tissue the scaffold of the hydrated membrane must possess large pores and high pore interconnectivity so that exchange can occur normally $[1,3]$. Besides that, permeability to water vapor and oxygen is also required to keep the cells alive [7].

Therefore, it is extremely important to study how geometry is affected, so it can be adapted accordingly to the application. Scaffold fabrication methods significantly affect the geometry of the membrane. Casting, electrospinning, and freezedrying methods are the ones that offer more control over pore diameter size and the porosity (usually greater than $90 \%$ ) of the membrane [3].

\section{$\underline{\text { Antimicrobial Action }}$}

Infections may occur in a wound, aggravating its condition slightly or even severely, causing the patient's death [8]. Therefore, to prevent it, microbial action must be eliminated. This attribute can be achieved by incorporating a material with antimicrobial properties into the membrane when developing a biomaterial. 


\section{Biopolymers as Materials for Wound Dressing}

Biopolymers have been a major target of study for the development of biomaterials since they are biodegradable and non-toxic, biocompatible, in addition to having low cost, easy processing, and promoting excellent adhesion and cell growth [1]. However, one of the biggest challenges faced in tissue engineering is to find a method of production that can be applicable on large scale. Some of the most studied biopolymers are chitosan and bacterial cellulose, which will be discussed in this review.

\section{Bacterial Cellulose}

Bacterial cellulose is produced through the biosynthesis of bacteria. This polysaccharide has many interesting characteristics for tissue engineering. In addition to being biocompatible, non-allergenic, and non-toxic, bacterial cellulose also has high porosity due to the formation of nanofibers ( $3 \mathrm{~nm}$ to $8 \mathrm{~nm})$, high crystallinity $(60 \%$ to $80 \%$ ), high hydrophilicity, high water holding capacity, and great mechanical properties, such as high strength tension and elasticity [7]. However, its production still lacks an efficient large-scale fermentation system (Figure 1) [7].

Figure 1. Bacterial cellulose membrane.

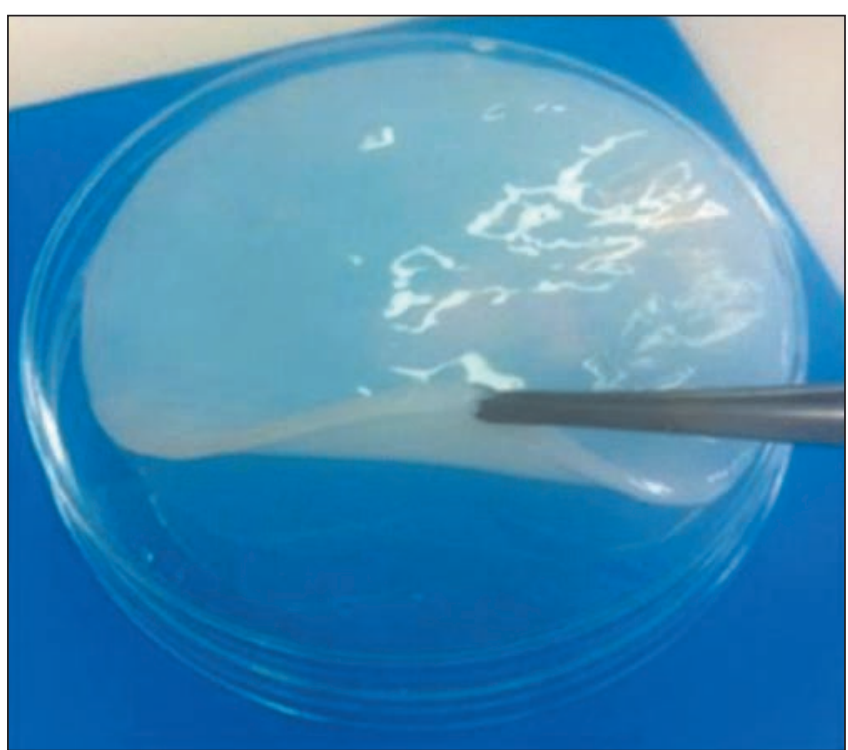

\section{$\underline{\text { Chitosan }}$}

Chitosan is a biopolymer resulting from the deacetylation of chitin, a polysaccharide present in the shell of crustaceans, some insects, mollusks, and in the cell wall of fungi (Figure 2)[8]. This biopolymer has great potential for study in tissue engineering due to its antimicrobial and healing

Figure 2. Pure chitosan membrane.

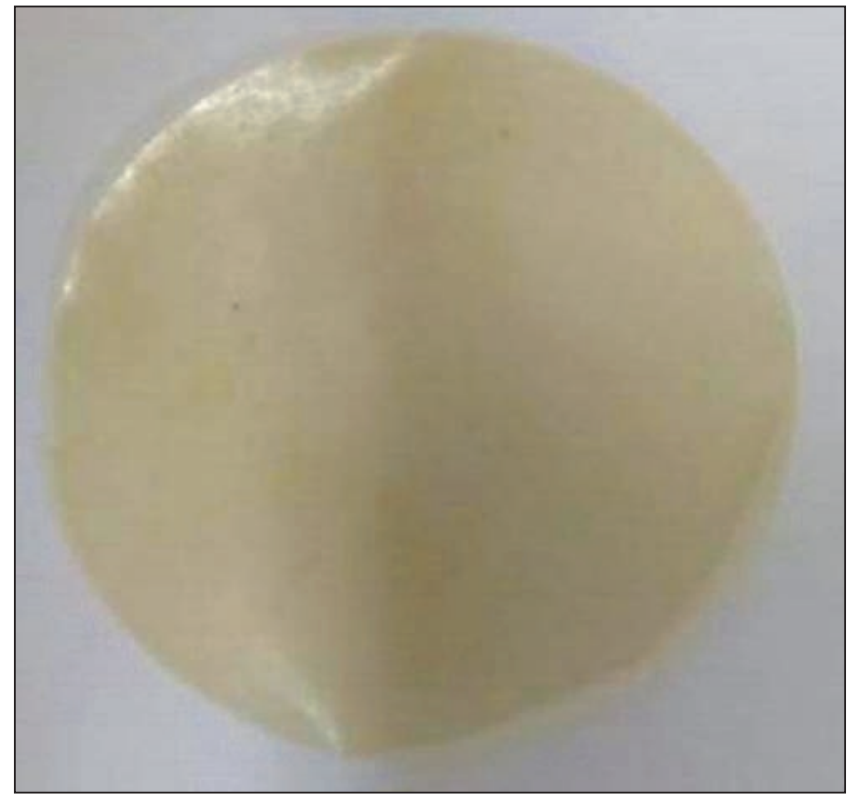

properties, in addition to being fully absorbable by the body [8]. To improve its properties, it is often used with additives and physical or chemical modifications [6].

\section{Recent Studies on Hydrated Membranes Characterization}

$\underline{\text { Wettability }}$

Polymer blends and treatments with other components are some of the used methods, which usuallygenerateresultswhosecontactangleisreduced. In the study realized by Silva and colleagues [6], chitosan membranes treated with glycerol, plasma, or glycerol and plasma, presented good results (Graph 1). 
Graph 1. The contact angle for pure chitosan membrane (MQ), plasma-treated chitosan membrane (MQ-P), glyceride treated chitosan membrane (MQ-G), and plasma glycerin treated chitosan membrane (MQ-GP).

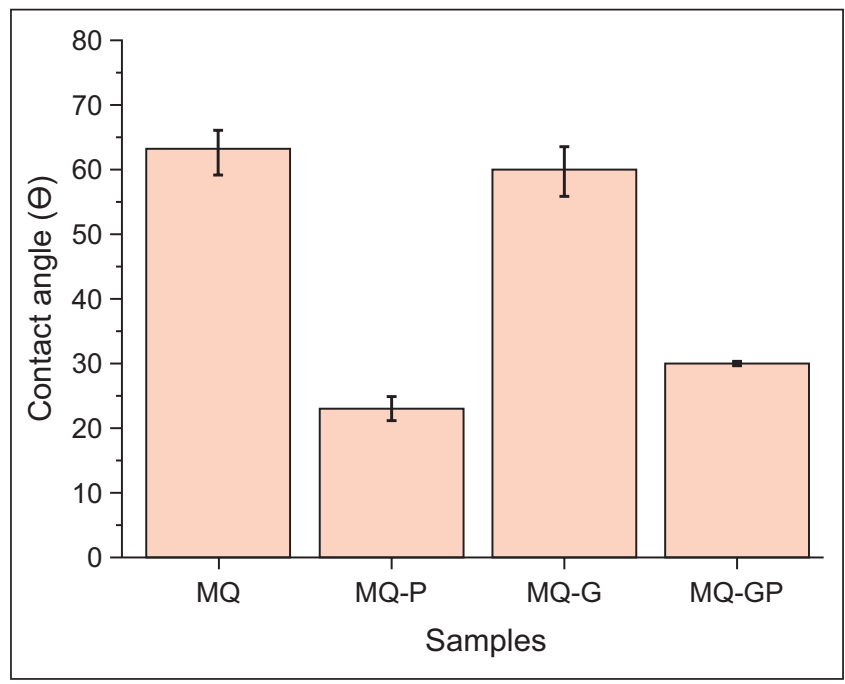

Pure chitosan membranes already show contact angles that qualify the material as hydrophilic but when treated with plasma, glycerin, or both, the contact angle can be strongly reduced.

Another study, in which corn starch was added to the bacterial cellulose membrane, also showed reduced contact angles over time for both membranes but especially when the addition was performed (Table 1) [9].

Table 1. Contact angle over time found in the analysis of the pure bacterial cellulose membrane and the sample treated with corn starch, glycerin, and water.

\begin{tabular}{cc|cc}
\hline \multicolumn{2}{c|}{ CB } & \multicolumn{2}{c}{ Sample } \\
\hline Time $(\mathrm{s})$ & Angle $\left(^{\circ}\right)$ & Time $(\mathrm{s})$ & Angle $\left(^{\circ}\right)$ \\
\hline 0 & 32.55 & 0 & 10.7 \\
5 & 30.45 & 5 & 6.6 \\
30 & 26.70 & & \\
\hline
\end{tabular}

\section{Geometry and Porosity}

Geometry is mostly affected by the chosen form of membrane production and by the concentration of the materials involved [3]. In a study performed by Alavarse and colleagues [10], the influence of different chitosan concentrations in a polymer blend with PVA was evaluated. The membranes were produced through electrospinning, which is one of the methods that best contributes to high porosity (Table 2) [3].

Table 2. Porosity percentage of the Polymer scaffold according to chitosan concentration.

\begin{tabular}{cc}
\hline Samples & Porosity (\%) \\
\hline PVA/Qui. 100/0 & $50.71 \pm 4.38$ \\
PVA/Qui. 90/10 & $41.52 \pm 1.8$ \\
PVA/Qui. 80/20 & $47.34 \pm 2.85$ \\
PVA/Qui. 70/30 & $49.44 \pm 3.79$ \\
\hline
\end{tabular}

The membrane with PVA/Qui. 70/30 presented the smallest nanofiber diameters (Graph 2), which is relevant since, the smaller the nanofiber is, the better it acts as a barrier against bacteria, allows oxygen diffusion, and has mechanical stability to act as a scaffold [3].

Graph 2. Mean and standard deviation of the nanofiber diameter and the behavior of the samples (with stars at the top of the standard deviation limit: samples with statistically equal mean diameters).

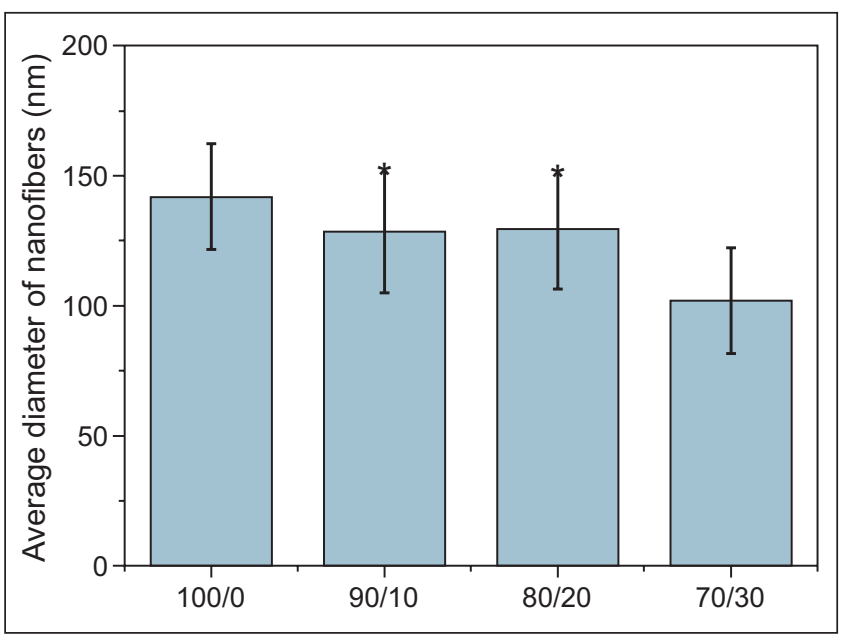

\section{Antimicrobial Action}

Chitosan itself already has antimicrobial properties, however, it depends on the concentration 
of chitosan. Therefore, for this reason, and since bacterial cellulose does not have those properties, micro, and nanoparticles of metals with such properties are used to enhance or add antimicrobial properties.

In a study performed by Fischer and colleagues [5], silver nanoparticles were added to a bacterial nanocellulose membrane (BNC) and the antimicrobial action for S.aureus and $P$. Aeruginosa bacteria was evaluated (Table 3).

Table 3. Data obtained from the antimicrobial assay with samples of pure BNC (bacterial nanocellulose) and BNC incorporated with NPAg.

\begin{tabular}{lcc}
\hline Sample & $\begin{array}{c}\text { Colonies (n) } \\
\text { of } \text { S. aureus } \\
\text { in 24 hours }\end{array}$ & $\begin{array}{c}\text { Colonies (n) of } \\
\text { P. aeruginosa } \\
\text { in 24 hours }\end{array}$ \\
\hline $\begin{array}{l}\text { pure BNC } \\
\text { incorporated }\end{array}$ & $3.1 \times 10^{5}$ & $1.8 \times 10^{3}$ \\
$\begin{array}{l}\text { BNC } \\
\text { bacterial } \\
\text { reduction (\%) }\end{array}$ & 160 & 23 \\
\hline
\end{tabular}

\section{Conclusion}

This study presented the potential dimension of hydrated membranes made of biopolymers. The materials and a few methods recently studied have great potential for exploration due to their satisfactory results in contemplating the necessary attributes in the membrane. However, the challenge is an economically viable way to produce the materials to be developed.

\section{References}

1. O'Briel FJ. Biomaterials \& Scaffolds for tissue engineering. Materials Today 2011;14(3):88-95. [Online]. Available: https:/www.sciencedirect.com/ science/article/pii/S136970211170058X.
2 Pires ALR, Bierhalz ACK, Moraes AM. Biomateriais: Tipos, aplicações e mercados. Química Nova 2015;38(7):957-971. [Online].Available: https:// www.scielo.br/j/qn/a/th7gjVpvdpthnctYbhtFznN/?la ng=pt.

3. Lanza R, Langer, R, Vacanti J. Principles of Tissue Engineering, Elsevier, Burlington, 2007, Chapter 2 (309-321). [E-book].Available:https://www. sciencedirect.com/book/9780123983589/principles-oftissue-engineering.

4. Latarjet J. A simple guide to burn treatment. Burns 1995;21(3):221-225. [Online].Available:https://www. sciencedirect.com/science/article/abs/pii/03054179958 0015G?via\%3Dihub.

5. Fischer MR, Garcia MCF, Nogueira AAL, Porto LM, Schneider ALS, Pezzin APT. Biossíntese e caracterização de nanocelulose bacteriana para engenharia de tecidos. Revista Matéria 2017;22(Suppl 1). [Online].Available:https:/www.scielo.br/j/rmat/a/ PCTW3X9zjG4HcYQtT4TYfCn/abstract/?lang=pt.

6. Silva JLM. Estudo das propriedades mecânicas de membranas modificadas de quitosana. 2018. Universidade Federal Rural do Semi-Arido, Bachelor's thesis. [Online].Available:https://repositorio.ufersa. edu.br/handle/prefix/4281.

7. Wojciech C, Krystynowicza A, Bieleckia S, Brown Jr., RM. Microbial cellulose: the natural power to heal wounds. Biomaterials 2006;27(2):145-151. [Online]. Available: https:/www.sciencedirect.com/science/ article/abs/pii/S0142961205007040.

8. Dallan PRM. Síntese e caracterização de membranas de quitosana para aplicação na regeneração de pele. 2005. Universidade Federal de Campinas, Doctorate's thesis. [Online].Available:http://repositorio.unicamp. br/jspui/handle/REPOSIP/267454.

9. Silva CM, Santos, ZM. Caracterização morfológica de membrana polimérica cb/amido, in Congresso Brasileiro de Engenharia e Ciência dos Materiais 2014:6917-6924. [Online].Available:http://www. metallum.com.br/21cbecimat/CD/PDF/404-030.pdf.

10. Alavarse AC. Desenvolvimento e caracterização de arcabouços à base de blendas poliméricas de PVA e de Quitosana para engenharia de tecido. 2015. Universidade Federal do ABC, Master's thesis. [Online].Available:https://propg.ufabc.edu.br/ biotecnociencia/Dissert_Defendidas/BTC-2015\%20 -\%20Alex\%20Carvalho\%20Alavarse.pdf. 